Meta

Journal des traducteurs

Translators' Journal

\title{
Dancing with Ideology: Grammatical Metaphor and Identity Presentation in Translation
}

\section{Chunshen Zhu et Junfeng Zhang}

Volume 60, numéro 3, décembre 2015

URI : https://id.erudit.org/iderudit/1036135ar

DOI : https://doi.org/10.7202/1036135ar

Aller au sommaire du numéro

\section{Éditeur(s)}

Les Presses de l’Université de Montréal

ISSN

0026-0452 (imprimé)

1492-1421 (numérique)

Découvrir la revue

Citer cet article

Zhu, C. \& Zhang, J. (2015). Dancing with Ideology: Grammatical Metaphor and Identity Presentation in Translation. Meta, 60(3), 387-405.

https://doi.org/10.7202/1036135ar
Résumé de l'article

Cet article commence par revenir sur un discours très médiatisé de Hu Jintao prononcé au cours de son mandat de président en 2008 et dans lequel il employait l'expression argotique chinoise " [nous] bu zheteng ", que le gouvernement chinois préféra ne pas traduire malgré les traductions existantes et les diverses options proposées par les dictionnaires chinois-anglais. Puis, cet article cherche à comprendre, sous l'angle de la métaphore grammaticale, pourquoi et comment cette expression, si pragmatique et dénuée d'arrière-pensée que fût son usage, a pu susciter toute une série de débats sur le plan idéologique au sujet de sa traduction. Pour ce faire, cet article réexamine le concept de métaphore grammaticale, notion-clé de la linguistique systémique fonctionnelle pour la description de l'évolution du langage de la congruence vers la métaphore. L'observation en traduction de cet élément de discours nous permet d'avancer que différents moyens textuels de présentation/dissimulation d'une participation humaine dans la transitivité sont cruciaux pour rendre compte de la fonction discursive des métaphores grammaticales et pour distinguer le " chaînon " entre expressions métaphoriques et expressions congruentes. À la lumière de la dissimulation de la participation humaine dans le processus de transitivité, cet article remarque également que c'est l'association du vague auto-allusif « nous » et des actions/situations défavorables, c'est-à-dire (causant du) désordre, suggérées par le terme zheteng qui a rendu une traduction explicite d'un point de vue sémantique idéologiquement moins souhaitable. Aussi le choix de ne pas traduire semble-t-il être un cas de manoeuvre discursive plutôt qu'un signe d'impasse sémantique. Afin de confirmer notre hypothèse théorique, l'article fait le lien entre ce cas et d'autres éléments de discours politique présentant des similitudes sur la scène politique internationale et démontre comment, la conscience fonctionnelle des métaphores grammaticales aidant, il est possible de concevoir une traduction mieux pensée en termes de sensibilité pour identifier la présentation/dissimulation dans le discours.
Ce document est protégé par la loi sur le droit d'auteur. L’utilisation des services d'Érudit (y compris la reproduction) est assujettie à sa politique d'utilisation que vous pouvez consulter en ligne.

https://apropos.erudit.org/fr/usagers/politique-dutilisation/ 


\title{
Dancing with Ideology: Grammatical Metaphor and Identity Presentation in Translation
}

\author{
CHUNSHEN ZHU \\ City University of Hong Kong, Hong Kong, China \\ ctzhu@cityu.edu.hk \\ JUNFENG ZHANG \\ Central China Normal University, Wuhan, China \\ david1998@126.com
}

\section{RÉSUMÉ}

Cet article commence par revenir sur un discours très médiatisé de Hu Jintao prononcé au cours de son mandat de président en 2008 et dans lequel il employait l'expression argotique chinoise «[nous] bu zheteng», que le gouvernement chinois préféra ne pas traduire malgré les traductions existantes et les diverses options proposées par les dictionnaires chinois-anglais. Puis, cet article cherche à comprendre, sous l'angle de la métaphore grammaticale, pourquoi et comment cette expression, si pragmatique et dénuée d'arrière-pensée que fût son usage, a pu susciter toute une série de débats sur le plan idéologique au sujet de sa traduction. Pour ce faire, cet article réexamine le concept de métaphore grammaticale, notion-clé de la linguistique systémique fonctionnelle pour la description de l'évolution du langage de la congruence vers la métaphore. L'observation en traduction de cet élément de discours nous permet d'avancer que différents moyens textuels de présentation/dissimulation d'une participation humaine dans la transitivité sont cruciaux pour rendre compte de la fonction discursive des métaphores grammaticales et pour distinguer le «chaînon» entre expressions métaphoriques et expressions congruentes. À la lumière de la dissimulation de la participation humaine dans le processus de transitivité, cet article remarque également que c'est l'association du vague auto-allusif «nous » et des actions/situations défavorables, c'est-à-dire (causant du) désordre, suggérées par le terme zheteng qui a rendu une traduction explicite d'un point de vue sémantique idéologiquement moins souhaitable. Aussi le choix de ne pas traduire semble-t-il être un cas de manœuvre discursive plutôt qu'un signe d'impasse sémantique. Afin de confirmer notre hypothèse théorique, l'article fait le lien entre ce cas et d'autres éléments de discours politique présentant des similitudes sur la scène politique internationale et démontre comment, la conscience fonctionnelle des métaphores grammaticales aidant, il est possible de concevoir une traduction mieux pensée en termes de sensibilité pour identifier la présentation/dissimulation dans le discours.

\section{ABSTRACT}

This paper begins with an account of a high-profile political speech event centring on a Chinese slangy expression '[we] bu zheteng' when it was used by the then Chinese President $\mathrm{Hu}$ Jintao in a 2008 speech, of which the Chinese government preferred a zerotranslation despite the existing translations and various choices already available in Chinese-English dictionaries. The paper then discusses from the perspective of grammatical metaphor how and why an innocent-looking pragmatic usage has given rise to a series of ideologically charged debates over its translation. To that end, the paper conducts a critical review of grammatical metaphor, a key Systemic Functional Linguistic concept in describing congruence-to-metaphor evolution of language. Our cross lingual observation of this translation-related speech event enables us to argue that different textual means of presentation/concealment of human participation in transitivity are key 
to accounting for the discursive function of grammatical metaphors and to discerning the "chain" between congruent and metaphorical expressions. In the light of concealment of human participation in the transitivity process, the paper also observes that it is the association between the vague self-referencing 'we' and the adverse actions/situations, that is, (causing) commotions, alluded to by the term zheteng that has made a semantically explicit translation ideologically less desirable. As such, this operation of zero translation appears to be an instance of discursive manoeuvre rather than a sign of semantic impasse. To substantiate its theoretical claim, the paper relates the case to some similar political speech events in the world's political arena and demonstrates how, prompted by this functional awareness of grammatical metaphors, one may devise a translation with better informed sensitivity to identity presentation/concealment in discourse.

\section{MOTS-CLÉS/KEYWORDS}

transitivité, métaphore grammaticale, traduction politique, transparence textuelle transitivity, grammatical metaphor, political translation, textual accountability

\section{Introduction}

One harmless-looking Chinese idiom, when used by a top communist party leader in China to indicate a social phenomenon and a political vision, has unexpectedly become a political speech event that has sparked off a vigorous series of debates over its translation, as well as the issue of social justice and government image it implies. The case, as observed in this paper, provides an interesting opportunity to look into the workings of power relations in an operation of translation, or resistance to translation as Venuti $(1995 ; 2008)$ would call it. To examine the discursive management involved in this case, especially with reference to identity concealment-presence of (human) participants in a transitivity process, the paper undertakes to critique and refine the conception of grammatical metaphor in Systemic Functional Linguistics, before applying it to an investigation of the speech event as a case study, with the aim of probing for a textually accountable understanding of identity concealment-presence in discourse and in translation as discourse.

\section{Resistance to Translation: Hu's 'we ... bu zheteng'}

\subsection{The Speech Event of (bu) zheteng: Its Background}

In his nationally-broadcast live speech on December 18, 2008 to senior officials of the Chinese Communist Party (CPC) in commemoration of the $30^{\text {th }}$ anniversary of China's reform and open-up policy, Mr. Hu Jintao, in his capacity as President of the country and the General Secretary of the Party, declared:

(1) 只要我们不动摇、不解急、不折腾, 坚定不移地推进改革开放, 坚定不移地走中国 特色社会主义道路, 就一定能够胜利实现这一宏伟蓝图和奋斗目标。

(English translation to follow; our emphasis)

The slangy term 折腾 (zheteng, underlined above), to the effect of (causing) commotions in English, is used in this passage as an intransitive verb rather than a noun or a transitive as it could otherwise be in the language. When negated by 不 $(b u)$, the utterance designates a hoped-for situation of social harmony devoid of zheteng, or commotions - 'as long as we ... do not zheteng,' it says in a colloquial and hence 
amicable manner, which is rather different from the norms of CPC discourse. Eight days later, the utterance appeared again in Hu's address to his comrades at a meeting of the CPC Politburo, referring to such kind of harmony as a prerequisite for the realization of a socialism with Chinese characteristics which, Hu believes, is the only track China will follow to succeed in its national development (People's Daily Online ${ }^{1}$. All of the official Chinese news agencies that run news coverage in English, China Daily, the Xinhua News Agency, and The People's Daily, have provided their English versions of the term as follows (underlines added to indicate its English translations):

(a) If we don't sway back and forth, relax our efforts or get sidetracked, but firmly push forward the reform and opening-up policy as well as adhere to socialism with Chinese characteristics, then this grand blueprint will definitely materialize.

(China Daily Online; our emphasis ${ }^{2}$ )

(b) Don't sway back and forth, relax our efforts or get sidetracked, but firmly push forward the reform and opening-up as well as adhere to socialism with Chinese characteristics. In that way, we will definitely achieve our grand blueprint and ambitious objectives (on realizing modernization in the middle of the 21st century).

(Xinhua Online; our emphasis ${ }^{3}$ )

(c) As long as we don't waver, don't slack off and don't 'zheteng,' and as long as we firmly push forward reform and opening-up and walk the road of socialism with Chinese characteristics, we are certain to be able to successfully realize this grand blueprint and achieve the goals of our struggle.

(People's Daily Online; our emphasis $\left.{ }^{4}\right)$

As we can see, among the three somewhat "official" versions, two different renderings were adopted: namely (don't) get sidetracked in 1(a) and (b), and (don't) 'zheteng' in 1(c). In other words, the action of zheteng (or the situation it may cause), negated in the phrase by the particle bu, was interpreted as "get sidetracked," or simply transliterated as zheteng.

\subsection{Attempts at a Translation}

The event marked one of the rare occasions where top Chinese officials would use a colloquial term to convey an important policy message. And, indeed, it transpires that the term has become much associated with the Chinese government's policy of maintaining social stability in the subsequent years. What was unexpected, however, is that the utterance has aroused a serious interest among bilinguals, translators, politicians, and translation scholars as to how it should be translated to make it accessible to the world at large. Even an in-service Chinese ambassador was reported to have joined in a heated debate about what (bu) zheteng means and how it can be best represented in English (People's Daily Online ${ }^{5}$ ). Here is a collection of renderings proposed on the Internet (People's Daily Online; see notes 4 and 5):

(2) (不)折滕 ([bu] zheteng)
a. (don't) get sidetracked
b. (don't) flip flop
c. (don't) sway back and forth
d. (no) dithering
e. (no) major changes 
f. (avoid) futile actions

g. (stop) making trouble and wasting time

h. (no) self-consuming political movements

i. (avoid) self-inflicted setbacks

j. (no) trouble-making

k. (don't) zheteng

1. (bu) zheteng

Chinese Translators Journal, the top journal in translation studies in China, published a forum article in $2009^{6}$ to review the translation, featuring a group of leading experts in translation/interpreting, namely Shi Yanhua (Ministry of Foreign Affairs), Du Yan (Interstate Liaison Department of the CPC Central Committee), Wang Pingxing (The Xinhua News Agency), Zhu Yuan (China Daily), Xie Qiao (China Radio International), Ju Zuchun (People's Liberation Army Nanjing Institute of International Relations), and Li Changshuan (Beijing Foreign Studies University). Their interpretations and suggested translations of $(b u)$ zheteng, as well as those listed above, seem to indicate that there has been more disparity than consent in interpreting $(b u)$ zheteng in English.

\subsection{Resistance to Translation}

The Chinese authorities appeared to have been caught rather unprepared for such a burst of enthusiasm about the translation of a trivial linguistic detail, and more importantly, the interpretation and perception of China's politics and its image the discussions about its translatability may induce. On December 30, 2008, at a press conference given by the Chinese State Council Information Office, upon the request of a Hong Kong journalist, the Office Director Wang Chen tried to explain in Chinese what (bu) zheteng means. But according to the report dated December 31, 2008 (National Population and Family Planning Commission of the People's Republic of $\mathrm{China}^{7}$ ), in lieu of a head-on explication, what Mr. Wang gave was tantamount to a reiteration of the assertion in the latter part of Hu's utterance, that is, "[the bu zheteng means to] adhere to a socialism with Chinese characteristics." Such a response left the interpreter serving on site virtually with nothing to interpret, and more importantly, it gave a signal that any attempt to elaborate, even by borrowing the 12-day-old official rendering (that is, "[don't] get sidetracked"), could be regarded as inadvisable on that particular occasion. Cornered by this "explaining by non-explanation," as it were, the interpreter resorted to "interpreting by zero-translation" and produced a pinyin (a Romanization system for Mandarin Chinese) version, namely (bu) zheteng, which does not commit itself to any semantic explication of the term in English. This unexpected rendering suggests that by then the Chinese authorities had not yet decided on a final official translation to convey the message to the world. As if to make a virtue out of necessity, Chinese media then praised the interpreter for his purported ingenuity, saying that he was creating a term that might eventually make it to English mainstream parlance. Since then, $(b u)$ zheteng has seemed to be accepted as the official English version of Hu's (不)折腾, despite all the alternative renderings proposed during the period. 


\section{4. (Bu) zheteng: Its Meaning and Usage in Chinese Discourse}

Elsewhere (Zhu and Zhang 2011), we have investigated the meaning and usage of the word zheteng, which can be summarized as follows:

Regardless of its dialectal background, the slang has been used in literary as well as general discourse since the $18^{\text {th }}$ century as the examples in 《漢語大詞典》 (Hanyu Da Cidian 2007 ${ }^{8}$ indicate. And the term has been extensively glossed in Chinese-English dictionaries (for example, $\mathrm{Wu}\left(1986^{\circ}\right), \mathrm{Wu}\left(1993^{10}\right)$, and DeFrancis $\left(1997^{11}\right)$ ) as: a) toss and turn; b) do sth. over and over again; c) range back and forth; d) manoeuvre; and e) cause physical/mental suffering, get sb. down.

Also, it was noted that the semantic nuance of the negator bu had been neglected in the discussion (Chinese Translators Journal 2009; see note 6), which is discursively meaningful when set against another common negator in Chinese, that is, bie (别). That is, when zheteng is negated by $b u$, the phrase bu zheteng tends to sound general and neutral in negating a hypothesized action of zheteng, as in this case. But when it is negated by bie, the phrase bie zheteng would indicate an imperative intending to deter a person from continuing with an on-going action of zheteng.

According to Wang in Chinese Translators Journal (2009: 59; see note 6), Deng Xiaoping has used the term on two occasions to designate "bourgeois liberalism" and social unrest, and the term has been officially translated as "turmoil" and "disorder" respectively in the Selected Works of Deng Xiaoping. Moreover, the data found on the People's Daily website (Zhu and Zhang 2011) show that as early as December 22, 1986, Li Ruihuan, a former carpenter-turned Politburo member and Chairman of the Chinese People's Political Consultative Conference (CPPCC), was using the term to refer to what had happened in China ( $\mathrm{Li}$ 2007: 60). Li seemed to be rather fond of this phrase for he used it on several other formal occasions, political or diplomatic, respectively in 1998 (Li 2007: 12), 1998 (People's Daily Online ${ }^{12}$ ), and 2001 (Xinhua Online $e^{13}$.

It is interesting to note that the opening clause of the following passage from Li's 1998 CPPCC closing remarks is almost identical to that of Hu's in wording:

(3) 只要我们不动摇、不松劲、不折腾, 专心致志, 艰苦奋斗, 再干一个二十年, 再干几 个二十年, 中国就一定能够以社会主义现代化强国的雄姿崛起在世界东方!

(People's Daily Online; see note 12)

As long as we don't waver, don't slack off and “bu zheteng” and as long as we work hard for another 20 years and several 20 years more, China is sure to rise as a socialist, modern, and strong power in the east. (Translated by the authors ${ }^{14}$ )

From the above, we can see that zheteng has been used in a very loose and general way even in China's formal political discourse to designate any political and cultural thoughts and deeds deemed as unorthodoxy by the Party's mainstream ideology prevalent at a particular period in its history. That is, any action that is likely to jeopardize the Party's leadership, or any action that can be an obstacle to the country's development along the "right path," especially those that would distract the government's attention from its agenda of, say, economic reforms and open-up.

This overview should suffice to make it clear that (bu) zheteng, despite its political overtone in a Chinese context, does not pass for a cryptic term in its own right in either general or political use. Yet, being a dead lexical metaphor, it does preserve certain semantic vagueness and downgrade the register by giving the saying a touch 
of informality and amiability, as most slangy expressions would. As HernándezCampoy and Cutillas-Espinosa (2010: 297, 308) have observed, such register downgrading can be found in "very formal [political] speech events" as well as in everyday utterances to serve, among other things, speakers' "specific situational goals," for instance "to design their desired personas."

\subsection{Who is the 'we'?}

Why have those semantically more meaningful translations of zheteng been disregarded? Or why has a zero-translation approach been viewed as more advisable? In other words, what has made Hu's (bu) zheteng so unique as to defy any attempt at a semantic interpretation? According to a $21^{\text {st }}$ Century article ${ }^{15}$, Hu's use of the dialectal phrase represents a register crossing-over that brings an informal northern colloquialism into a formal political discourse. This, indeed, is a phenomenon difficult to perceive or appreciate outside the Chinese context. Yet, two observations can be derived from this journalistic comment, which are more significant in discursive terms. First, this crossing-over is in nature a register downgrading, which, whilst communicating a note of camaraderie, is suggestive of a reduced degree of seriousness of whatever the term zheteng may have implied. For, as we have seen, the term has often been used in general discourse to indicate trivial or petty annoyances. Secondly, as zheteng is a "dead metaphor" (see Newmark 2001a: 84-96; 2001b: 104-113 for discussions of the translation of types of lexical metaphors) in Chinese, literally meaning "twist [and] toss," identification of its specific referent(s) is highly contextdependent. In other words, the exact meaning of Hu's $(b u)$ zheteng is vague and uncertain, and is thus open to different interpretations, as the debates and the suggested semantic renderings listed above have proved.

But more importantly, to resolve the uncertainty in meaning or the openness to multiple readings of zheteng, as well as to decode the political implications behind it, the identity of the doer and the goal of the transitivity process have to be established. Yet, given the fact that the Party is viewed as representing the whole nation, with the absence of the goal, the referent of the first-person plural pronoun我们 (wo-men 'we') in Hu's utterance becomes very vague in a politically sensitive context like this. As such, the actor and the action of zheteng have entered a mutually-defining correlation. Indeed, a quick overview of the ensuing observations made by the general public on the Internet shows that different social strata have supplied their own interpretations of the 'we' and specified the zheteng accordingly in an attempt to articulate their views as to who is to blame for the commotions of zheteng in the country's contemporary history (Xinhua Online ${ }^{16}$ ). By the same token, any specification of the meaning of the zheteng will lead inevitably to that of the identity of the 'we,' which, in turn, will call for the identification of another human participant, the recipient of the zheteng, and perhaps the circumstantial elements as well, to furnish an ideationally complete transitivity process of 'who zheteng whom,' and under what circumstances.

And it is this question about the identification of the agent that prompted us to review Hu's speech event in the light of grammatical metaphor, with a view to examining ideological implications of agent-information concealment in political discourse and its translation. 
To that end, the concept of grammatical metaphor has to be reviewed and consolidated.

\section{In Quest of the Agent: From Grammatical Metaphor to the Congruent}

\subsection{Conception of Grammatical Metaphor in Systemic Functional Linguistics}

First of all, the use of metaphor in grammatical metaphor suggests there is an analogy between macro evolution of language and micro evolution of a word's meaning from literal to metaphorical. Take nominalization for instance: as a grammatical metaphor, it represents, in Halliday's words, "a process, congruently construed as a verb, is reconstrued metaphorically as a noun" (Halliday 1999: 90), although grammatical metaphor "involves much more than just turning things into nouns." More specifically, in his An Introduction to Functional Grammar, Halliday (1985) defines grammatical metaphor as a linguistic phenomenon inherent to language evolution, of which there are two categories: ideational and interpersonal grammatical metaphors. Whilst the interpersonal grammatical metaphor, a "metaphor of mood (including modality)," has to do with the expression of the speaker's attitude, the ideational grammatical metaphor, being a "metaphor of transitivity," acts on information presentation regarding transitivity processes (Halliday 1985: 321; for interpersonal grammatical metaphor, see sec. 10.4). As we will focus on the transitivity process of "we bu zheteng," the ideational grammatical metaphor is our main concern here and will be referred to as GM in the remainder of this paper.

Halliday (1985: 320) derived the concept of GM by adopting a looked-at-fromabove perspective in his comparison of lexical metaphor and GM. Taking this perspective, Thompson has given "a provisional definition of grammatical metaphor as: the expression of a meaning through a lexico-grammatical form which originally evolved to express a different kind of meaning," of which lexical metaphor can be "seen as a sub-category" and by which, as Thompson asserts, "[t]he expression is the meaning" (Thompson 1996: 165; emphasis in the original; see also Taverniers 2003: 6).

\subsection{Discursive Function of GM: Concealment of Human Participants}

A list of thirteen "principal types" of GM in its lexical/phraseological realization is provided in Halliday (1999: 91, Figure 6.6, quoting Halliday and Matthiessen 1998), covering almost every aspects of lingual representation of human experience from congruent to metaphorical in English, ranging from 1. quality to entity (for example, unstable to instability) and 2. process to entity (for example, transform to transformation), to 9. relator to process (for example, then $=$ follow) and 13. entity to [expansion] (for example, the government [decided] = the government's [decision], [a/the decision] of/by the government, [a] government(al) [decision]). But the ubiquity of its textual manifestation at lexical and phraseological levels should not be taken to mean that GM is merely a lexical/phraseological-level transformation of experience into meaning, especially when its discursive function is taken into account. As Halliday points out, grammatical metaphorization, being a "metaphor of transitivity," takes place "by means of its central construct, the clause," and a clause, anchored to a finite verb, furnishes "a unit of experience" in cognition and "a unit of information" in communication (see Halliday 1999: 94, 106). Viewed from the clause level, a GM can be 
seen as registering a transformation from the congruent, that is, a complete transitivity process including the actual doer (Agent or Subject) and goal (or Object) in the external world, to the metaphorical, that is, a linguistic realization that obscures such actual doer and/or goal. To identify a GM, one has to use a "congruent" structure as the reference point. And a congruent structure, as "informally glossed" by Thompson (1996: 164), expresses the meaning in a way "closer to the state of affairs in the external world." Against its parallel congruent structure, a metaphorical one would appear less "adequate" in representing the external world, due to the loss or the demotion (from the unmarked thematic status) of "the doer of the process," or the disappearance of "both Subject and Finite," for instance by way of nominalization (Thompson 1996: 166, 171). The disappearance of the Subject and Finite, we may further observe, can lead to the disappearance of the goal or Object of the process. All these, in our terms, contribute to, or rather, enable, concealment of the information about human participant(s) to various extents.

Qualifications by "provisional" and "informally" in Thompson above suggests a lack of definitiveness, in the sense that it is not always a straightforward matter to tell a metaphorical structure from its congruent origin, despite those explicit lexicogrammatical manifestations in Halliday's list as sketched above. In Halliday's words, " $t$ ]here is no very clear line to be drawn between what is congruent and what is incongruent” (Halliday 1985: 327). Thompson (1996: 167) also admits to this uncertainty, noting that technically "we cannot always decide how best to unpack metaphorical meanings." In our view, the uncertainty can be a bottleneck in the development and application of GM theory, limiting its explanatory power in discourse analysis for translation studies or other more general purposes. Hence, further refinement is necessary.

If shedding the doer, among others, is the primary feature of a GM, then different lexico-grammatical means of obscuring the doer's identity can be regarded as metaphorical, too, albeit to a lesser degree. For instance, an indirect speech, which conceals the original speaker, is an interpersonal kind of GM (Halliday 1999: 98). Indeed, it has been observed that for a metaphorical expression, there can be a "chain" of congruent ones marking respective degrees of closeness to the state of affairs in the external world, or leading to "the least metaphorical [or] maximally simple" structure (see Halliday 1985: 328, 329). This has much to do with the fundamental mode of understanding and the nature of discourse as representation of this understanding, i.e., humans' experience of, and their relationship with, the external world, as well as their perception and conception of such experience itself. In her study of understanding, Newton (1996: 137-138, 142, 145) maintains, the most fundamental (or "built-in" from infancy) mode of understanding ourselves is understanding ourselves "as agents," and understanding others "as extensions of our agency made possible by communication," whilst communication, by definition, is a kind of interrelation perceived. Thus, understanding communication, according to Newton, is just "a short step" further from understanding other persons. And to us humans, "objects become meaningful as a function of perceived interrelations with other objects (including ourselves)" (Bransford and McCarrell 1977, quoted in Newton 1996: 80). In other words, to express such understanding of the world, i.e., objects including (other) humans, the more specifically the human agent is identified in the process, the more fundamental, or congruent, a discursive structure will be. Hence, 
provided the goal or object of the verb is contextually identifiable, utterances like a child's "I want ...." or Caesar's famous "I came, I saw, I conquered." (Veni, vidi, vici) are of a typical congruent structure, as far as agent-presence is concerned.

In his characterization of different categories of GM, Halliday posits, "Like metaphors of the traditional, lexical kind, grammatical metaphor always involves shifting towards the concrete... by making analogies with what is familiar and perceptible. The most accessible type of phenomenon is a 'thing'... and the category which construes such entities is the noun. The noun is thus the ultimate target of the analogy" (Halliday 1999: 94). This "ultimate" category of GM, by being manifested as a noun, makes the presence of participant(s) syntactically optional (as in [his] writing) or even unnecessary (as in the writing). Thus, as far as participant referencing is concerned, GMs manifested as clausal transitivity processes are more congruent. Among these GMs, those with the presence of specific participants, human participants in particular, are more congruent than those presenting participants by partially concealing their identity in a vague, general referencing; and the latter, in turn, are more congruent than those that totally conceal the participants from the process, as seen in passives without the by-phrase (for a detailed discussion of the syntactic status of the agent in English and Chinese passives, see Zhu 1996). As such, scientific discourse (taking weather forecast as a convenient example) by definition bespeaks the quintessence of GM at the fundamental, generic level because of its perpetual attempt to objectify processes as physical facts in the external world, shedding the underlying mental process of perception by concealing the human observer, which Halliday (1985: 325) would call "a conscious being."

In her characterization of the concept of GM, Taverniers defines metaphor as "variation in the expression of meaning" (2003: 6; emphasis in the original) and therefore, a GM takes effect via a choice on the lexico-grammatical plane of language rather than merely on that of the lexis. According to Martin (2003: 2), GM provides "a pathway from grammar to discourse semantics, and from discourse semantics to context that had not been available before." However, as noted above, the discerning of this pathway is dependent on the identification of human participant(s) in the process of a given GM.

Let us take the following pair from Halliday (1985: 328) as an example:

[Metaphorical] Advances in technology are speeding up the writing of business programs.

[Congruent] Because technology is getting better people can write business programs faster.

It has to be noted that, apart from the provided congruent version where the doer of the writing (of business programs) is presented, embedded in all the other elements there are "simpler" processes that involve a human doer:

Technology: people produce technology

Advances in technology: people advance technology

The writing: people write things

Speeding up: people write business programs - people use technology to write business programs - people use technology, which is now more advanced, to write business programs - people write business programs faster 
The identity of the doer (people) in each of the above processes may be further specified to various degrees and the structure becomes more congruent accordingly. In actual discourse, one metaphorical structure can involve more than one GM depending on the layers of embedment. And contextualization will reveal more of such layers. For example, as in this case, more specific identification of the people (i.e., plural vs. singular, general vs. specific), as well as the business programs, the type of technology, and the circumstances of the writing, will lead to a description cognitively closer to the real state of affairs. Thus, when Halliday (1985: 329) maintains that "the least metaphorical wording will always be the one that is maximally simple," we have to note that it is "simple" not in terms of the structure of process, nor in terms of wording (in the sense of plain English), but in terms of the degree of explicitness in representing human participation in the process to facilitate understanding. And this degree of explicitness is, in turn, determined by the thematic status and specificity assigned to the human participant in question, that is, by the way it is presented (for example, absence or presence as a direct actor/goal, or as an identifiable individual or a generally-referenced entity). Therefore, the simpler or the more congruent a structure is, the less effort it should require in processing the transitivity information it represents.

Since it is practically impossible to establish the ultimate congruent origin of a GM, the quest for congruence has to be made contingent on the purpose of the expedition, as Halliday has rightly pointed out:

How far does one go in this direction [of grammatical metaphor] in the course of textual analysis? There is no universally valid answer to this question, suited to all occasions; it will depend on what the analysis is for, and what one is trying to achieve by it. (Halliday 1985: 331-332)

With a view to describing GM's discursive function, however, a question is always of interest to ask: Why should a non-human element have to be presented as an unmarked theme? Or, what effect has been achieved by removing the human doer from its thematic status? In this connection we can see that, by promoting a nonhuman element to an unmarked theme (for example, as an actor or a sensor), metaphorical expressions provide the speaker with a series of means either to demote the human participant - which should have been present in the transitivity as the agent in the real-world state of affairs - to a status of indirect participant (for instance as an attribute of a process-turned "thing" as in his writing), or to blur or totally block its presence as seen in Halliday's GM example above. A further example can be borrowed from Halliday as follows:

[Metaphorical] The argument to the contrary is basically an appeal to the lack of synonymy in mental language.

[Congruent] In order to argue that [this] is not so [he] simply points out that there are no synonyms in mental language. (Halliday 1985: 331)

In the above pair, a pronoun he is added to remove one of the GMs by presenting a human doer, although the added this has to be further contextualized for the human participant in its embedded process to become perceivable.

In his article, Halliday gives a series of metaphoric variants, providing a further illustration of the "chain," or increasing degrees of grammatical metaphorization (Halliday 1999: 96). 
1) glass cracks more quickly the harder you press it

2) cracks in glass grow faster the more pressure is put on

3) glass crack growth is faster if greater stress is applied

4) the rate of glass crack growth depends on the magnitude of the applied stress

5) glass crack growth rate is associated with applied stress magnitude

In variant 1), the presence of the agent you, albeit in the subordinate process, helps mark the structure as more congruent than the rest on the list. Yet an even more congruent variant can be derived from it by rendering the agent more conspicuous: you crack glass more quickly if you press it harder.

It is therefore worth noting that, when objectifying the process by thematizing a non-human participant, a metaphorical expression, by de-thematizing, generalizing, or concealing the presence of a human participant, can have the effect of mitigating the discursive association between (human) participant(s) and process. And since recovering the identity of the human participants concerned beyond the lexicogrammatically formulated process depends heavily on the knowledge of the context, access to such contextual information may serve as a further lever to control the interpretation of the message, usually to the speaker's advantage.

\subsection{Between Metaphor and Congruence: Uncertainty Revisited in a Cross- Lingual Context}

In performing this function of identity presentation, lexico-grammatical manifestations of GM between two languages may not always demonstrate a one-to-one correspondence. For instance, one of the findings of Yang's (2008: sec.4 462) investigation, which has a focus on nominalization, is that Chinese and English can be "similar in their range of GM categories," but not in the subdivisions of all the GM types. According to Yang, in Chinese a GM can appear very similar in form to its congruent origin since Chinese nominalization takes place mainly by using a non-nominal word (for example, a verb or adjective) directly as a noun, i.e., without adding any morphological marking. (See Yang 2008: 463, 475) One factor Yang did not seem to have taken into account, though, is the major discursive function of GM in demoting or concealing (human) participants, which is often matched in Chinese in the form of a so-called "subjectless" sentence. (See our discussion below. Incidentally, the use of such sentences may probably serve to explain why Yang has also found that GMs are less extensively used in Chinese discourse.)

The following is one of the examples Cheng (1994: 122) gives to illustrate (English) GMs when introducing Systemic Functional Grammar to the Chinese audience:

(4) 1966 witnessed the devastating beginning of the Cultural Revolution.

Since there is no form in the Chinese language to match the sensor-concealing GM in the mental process of 1966 witnessed..., Cheng gives the following as its Chinese translation, where a third-person general referencing 人们 (ren-men 'people') is added to replace 1966 as the sensor who does the witnessing:

a. 1966年, 人们亲眼目睹了中国文化大革命浩劫的开始。

[In 1966, people witnessed the beginning of the devastating Cultural Revolution in China.] 
In Cheng, the above GM version is set against a congruent one, where the firstperson group referencing we, that is 我们 (wo-men in Chinese), is used in both the English sentence and the provided Chinese translation to replace people to increase the specificity of the human presence:

b. We witnessed the devastating beginning of the Cultural Revolution in China in 1966.

1966年, 我们亲眼目睹了中国文化大革命浩劫的开始。

[In 1966, we witnessed the beginning of the devastating Cultural Revolution in China.]

The pair shows that, at least for Cheng, the we-version is more congruent than the 'people' one, since it denotes a more specific identity. But if we follow Halliday's metaphor-congruence transfer from the fifth day saw them at the summit to they arrived at the summit on the fifth day (Halliday 1985: 322), the transitivity at issue in Cheng's pair should be the material process of begin rather than the mental one of witness. Such a realization relates Cheng's metaphorical version to an even more congruent representation where the human participant responsible for the principal process is pinpointed: Mao started the Cultural Revolution in China in 1966.

Notwithstanding, Cheng's use of we and 'people' in the above examples has affirmed, albeit unwittingly, our argument that (human) participant concealment or identity generalization plays a key role in GM formulation. Other things being equal, we may thus say of the same participant, a first-person expression is more specific, hence congruent, than a third-person one; and a singular one is more congruent than a plural one, as the Mao-version above identifies the doer in a way more specific than any group-referencing.

To conceal the (human) participant completely in Chinese, a "subjectless" sentence, among others, may serve the purpose, in which a predicate verb can go without the subject. For example:

(5) 讲这么大声, 让人听了心烦

['speak so loudly, make people annoyed' - (A certain person or group of people) speak loudly, (he/they) annoy(s) (other) people.]

In this sentence, the doer of the speaking is totally concealed and the human goal of the making (i.e., being annoyed) is generalized. The sentence, with the 'so' suggesting it refers to a specific event of loud speaking, can be matched by a GM expression in English which likewise conceals the actor and generalizes the goal:

a. The loud speaking annoys people.

And a more densely packed metaphorical version can be used to conceal all the human participants:

b. The loud speaking causes annoyance.

Therefore, any structures in either Chinese or English that de-thematize, generalize or block the presence of a human participant contribute to its demotion to varying extents. Since (human) participant demotion has been regarded as the major discursive function of a GM, such structures will serve to trace out "metaphorical kinship" on the "chain of metaphorical interpretations leading ... to something we might consider to be [the] congruent form [of the GM in question]" (Halliday 1985: 328). 


\section{Hu's 'we bu zheteng' Seen as a Grammatical Metaphor: Formation, Function, and Effect}

Let us now return to Hu's speech event. Given the fact that when situated in a context, ideational and interpersonal nuances of an utterance are not strictly imperceptible, the degree of information concealment in Hu's 'we bu zheteng' by means of identity generalization can be further determined by placing it alongside other options for identity generalization or concealment in Chinese, from the one with the strongest self-reference in 1) to the total omission in the subjectless form of 4):

1) 只要我们不折腾 ('so long as we do not zheteng')

2) 只要大家不折腾 ('so long as nobody zheteng')

3) 只要人们不折腾 ('so long as people do not zheteng')

4) 只要不折腾 ('so long as [there is] no zheteng').

Whilst keeping the identity of the actor of zheteng general, Hu's use of the version with the strongest self-referencing indication can be regarded as a discursively desirable choice, for 'we' in the utterance as a whole covers a series of processes with varying socio-political overtones. That is, with the first three negated processes, namely sway back and forth, relax efforts, and get sidetracked (following the China Daily translation, see below), the remaining ones all indicate highly advocated actions and hoped-for achievements which allow for, or rather call for, a stronger self-reference:

（6）只要我们不动摇、不解急、不折腾, 坚定不移地推进改革开放, 坚定不移地走中国 特色社会主义道路, 就一定能够胜利实现这一宏伟蓝图和奋斗目标。

If we don't sway back and forth, relax our efforts or get sidetracked, but firmly push forward the reform and opening-up policy as well as adhere to socialism with Chinese characteristics, then this grand blueprint will definitely materialize.

(China Daily Online; see note 2)

But, being in plural, the self-referencing is not the strongest if compared with the first-person singular $I$. In this connection, one may recall the American President Barack Obama's much reported remark I screwed up in February 2009 regarding the nomination of Senator Tom Daschle for the post of secretary of health and human services. ${ }^{17}$ In contrast, Hong Kong's then Chief Executive Mr. Donald Tsang Yamkuen had commented on the territory's political reform when responding to Hong Kong's Legislative Council on 15 January 2009, saying: We shouldn't cause more trouble. ${ }^{18}$ Whilst Tsang's words carry a note of formality and seriousness, Obama's screwed up sounds closer in both meaning and register to Hu's (bu) zheteng. But similarity between the two ends once we look at the ideational aspect of their utterances in terms of participant presentation in the transitivity process. In Obama's, there is a specific actor $I$ and a contextually inferable goal of the action screwed up, whilst in Hu's there is a vague 'we' with no clear reference to the goal or recipient of the action zheteng. The Chinese 'we,' to be sure, apart from being a pure self-referencing plural pronoun, can either be an inclusive we referring to both the speaker and the audience, or an exclusive we meaning you the audience (Wang, Wu et al. 1983: 13-14). To create vagueness by taking advantage of we's group-referencing function is also noted in English discourse. As Larcker and Zakolyukina's research on financial executives' narratives shows, because of its general "group referenc[ing]" function, frequent use of we, like the use of impersonal pronouns such as everybody, 
anybody and nobody, appears to be one of the textual signs of speakers' dissociation from their words when communicating a negative message, whilst the use of the first-person singular pronoun I may imply a stronger commitment to one's statement (Larcker and Zakolyukina 2010: 9, 10, 12, 25, 33, 53, 54).

As such, Hu's 'we [bu zheteng]' is similar to Tsang's we [shouldn't cause more trouble] in terms of non-specified group referencing. Also, it is interesting to note that both statements have avoided identification of the (human) goal, that is, "[(bu) zheteng] whom" or "[causing trouble to] whom." Admittedly, in view of the immediate situational context of Hu's speech, it is arguable that his 'we' may refer to: a) the Party, of which Hu was then the Secretary General, and its government; and/or b) the Chinese people in general, whom the Party claims to lead, govern and represent. Shu in Chinese Translators Journal (2009: 58; see note 6), for instance, takes it to mean both the Party and the populace, whilst Xie and Ju in the same article interpret the 'we' as referring to policy-makers, in particular those at the "highest level" (Chinese Translators Journal 2009: 60-61; see note 6). These two interpretations point to entirely different political implications with a direct bearing on the perception of the zheteng and the party who may suffer from it. As a matter of fact, the vagueness has led to heated discussions on China's Xinhuanet where the 'we' has been taken to mean, in a rather populist vein, (certain) government officials, and zheteng the social problems they have allegedly caused. For example, $76 \%$ of the netizens in an online survey on the Xinhua website believed that Hu's remark 'we bu zheteng' was to tell government officials not to zheteng the ordinary people with various senseless and capricious policies. On the other hand, as seen in the survey, there are also a number of other interpretations which, for instance, identify zheteng with fluctuations of the stock or property market and 'we' those parties who should be held responsible for any dire consequences (Xinhua Online; see note 16).

Viewed from a systemic functional linguistic perspective of the three metafunctions, namely ideational, interpersonal and textual, the discursive function of the lexico-grammatical formulation of Hu's grammatical metaphor 'we bu zheteng' can be summarized as follows:

1) Interpersonally, the use of the slangy idiom $(\underline{b u})$ zheteng has helped to downgrade the register of the otherwise formal and didactic speech and thus serves to reduce the distance between a political leader and his audience on the occasion.

2) Ideationally, besides the intrinsic vagueness of the idiom as a lexical metaphor, the use of the group-referencing first-personal plural pronoun 'we' in association with the intransitive zheteng contributes to concealing the identity of the human participants in this transitivity process by way of generalizing the actor and omitting the goal, thus serves to increase the distance between the speaker or his Party and the action or consequences of zheteng.

In China's domestic discursive context, regardless of the illocutionary motivation behind the utterance, the perlocutionary effect of this homely, slangy term in the given political milieu turns out paradoxically to be one of defamiliarization as we noted elsewhere (Zhu and Zhang 2011). And the response it has attracted varies from audience to audience (Party officials, the mainstream media, and the populace on the Internet).

In this light, the request at the press conference for the spokesperson to clarify what the zheteng means can be viewed as an attempt to seek official explications of 
a socio-political phenomenon that, as Ju (Chinese Translators Journal 2009: 61; see note 6) puts it, "is nonexistent in Western political culture." The zero-translation adopted on that occasion shows that the interpreter was caught unprepared in the sense that he, and perhaps the spokesperson, had not been given the authorization, or empowered, to spell out in his own terms the information concealed in the phrase other than reiterating Hu's original words. In other words, the bowdlerizing zerotranslation has firstly prevented the Chinese president from sounding as slangy, or "vulgar," as Obama, or as matter-of-fact as Tsang. Secondly, as far as the crucial issue of public imaging (as well as the differences between the underlying political cultures) is concerned, it has effectually obviated a perhaps unwanted extension of the perlocutionary effect of Hu's utterance on Chinese society beyond its domestic context. Indeed, judging by the attention the term's translation has attracted among critics and the mainstream media, a discursive issue of information concealment is deflected from its political, cultural, and social implications and turned into technical speculation about how to translate the slangy phrase into English "correctly."

Yet viewed from the angle of information management, the question about whether the utterance as a whole is translatable or not depends first of all on whether there are any means in English to avoid specifying the identity of the doer of the zheteng, if the already fuzzy 'we' has been deemed to have too strong a self-referencing indication to be associated with an action when its adverse aspects are spelt out in English.

\section{Translating Hu's “we bu zheteng” as a Grammatical Metaphor: Identity Presentation}

As we have noted above following Halliday, GM is different from semantic metaphor on the one hand and much more complex than lexical nominalization on the other, so its realization has to be perceived on the clause rather than word level. In this light and based on a close examination of the existing English translations of Hu's 'we bu zheteng,' we have argued that degrees of concealment of the human participant(s) in the transitivity process can be used to gauge the grammatical metaphoricality of a clausal form to help address the uncertainty surrounding the notion of congruence, which is key to identifying a grammatical metaphor. That may also explain why talking about translating (bu) zheteng as a dead, slangy metaphor has so far generated more heat than light. Since the Party's image is at stake in semantically explicating the slang, a translation has to take into consideration the presence of the actor referred to as 'we' that is supposed to be the doer of the string of actions mentioned in Hu's passage. And below we are offering a more specific deliberation on identity presentation in translation, illustrated by our experimentation with the translation of the utterance as a grammatical metaphor on the clause level:

Translation by definition lifts the source text out of its domestic context and exposes it to foreign, and not necessarily always friendly, interpretations. In Hu's case, a non-Chinese interpretation may be unlikely to maintain the source text's openness and implicitness in self-referencing to accommodate all those processes in the passage. For instance, a translation proposed by Wang in Chinese Translators Journal carries a strong subjective volition that is not found in the source text: "We will not waver, we will not slack, we will not sidetrack" (Chinese Translators Journal 2009: 60; see note 6). 
On the other hand, the China Daily translation of get sidetracked, which attracts much less attention than the zero-translation rendering, has obviously tried to tone it down (see Shi and Zhu in Chinese Translators Journal 2009: 58, 60, who find the translation either too weak or too vague), probably for fear that the association of the derogative meaning of zheteng with the 'we' be unwantedly played up in an international context. But can we perceive the Cultural Revolution in China's contemporary history, political/power struggles of the kind Hu's zheteng is believed to allude to (Shi and Zhu in Chinese Translators Journal 2009: 58, 61 respectively), simply as a case of getting sidetracked?

Furthermore, would this toning-down still be necessary if the 'we'-actor is dissociated from the adverse process with a GM-prompted rendering to free, so to speak, the translator of possible - and understandable - trepidations over the issue of the Party's image, when the lexical metaphor zheteng has to be semantically spelt out in English? Since the translations we have consulted (see above) show that translating (bu) zheteng itself should not be a linguistic impasse, by following the hint of Obama's screwed up, the term can even be rendered in a way to bring out its slangy tone, provided an awareness of the actor-concealing function of GMs has alerted the translator to an identity-sensitive management of the agent-process association. To that end, our revised version of the China Daily translation may serve as an illustration: "So long as there is no wavering, no messing about, so long as we do away with indolence, and firmly push forward [...]."

The rendering has shunned the self-referencing we by using a metaphoric therebe structure, ${ }^{19}$ until the tone of the passage becomes more upbeat. In other words, we is used here to identify the agent and to associate it with a more positive image.

\section{Discussion and Concluding Remarks: GM as a Textual Enabler for Information Concealment in Translation}

In this paper we have presented a detailed account of a speech event in which the use of zero translation has provided a rare opportunity to observe translation in an ideologically sensitive situation, a critique of grammatical metaphor to advance our understanding of the concept in Systemic Functional Linguistics by characterizing its discursive function of concealing human participation in transitivity processes, and a case study of the speech event in which the refined conception of GM is applied in investigating identity presentation in political discourse and its translation. The study as a whole argues that: 1) it is the demotion and dethematization of the (human) participant in its transitivity process that makes a linguistic form less congruent; 2) in this sense, nominalization is powerful in making a GM not because of the nominalization per se but because of the demotion and dethematization of human participants facilitated by the nominalization; and thus 3) functionally, GM is more than grammatical nominalization in that it provides a textual means for concealment of agent-related information. In return, such a realization of GM's discursive function may sensitize the translator to the issue of information management in interpreting the source text and in formulating a target text, with referencing to human participants as an indicator. As our case study shows, such sensitivity may alert the translator to GMs as a textual resource in producing a more subtly nuanced rendition, especially when the source text is an ideologically sensi- 
tive text and certain resistance to explication and, by extension, to translation, is involved.

Given the Chinese political milieu prevalent at the time, the resistance of Hu's fuzzy 'we' and vague zheteng to explication is seen in the spokesperson's evasive explanation at the press conference, and the utterance's resistance to translation is manifest in the interpreter's opaque zero translation, as well as the authorities' acceptance of, and indeed preference for, the rendering over semantically more meaningful alternatives. Understanding GM in terms of its discursive function of concealment of information, therefore, will help translators develop a finer-grained conception of resistance in translation as described by Venuti $(1995,2008)$ and a discursively more nuanced rendering if necessary, by identifying what has been concealed in the source text and hence maybe resistant to translation, as well as by determining whether and how to let it remain resistant or otherwise, and why such management of identity presentation is desirable in view of the pressure of the institutional power they operate under.

\section{ACKNOWLEDGMENTS}

This paper is the joint output of the first author's Project No. 7004323 funded by the City University of Hong Kong and the corresponding author's Project No. 14YJA740056 funded by The Chinese Ministry of Education Humanities and Social Sciences Foundation (Project Name "A Study on the Implicitness in Chinese Diplomatic Discourse and Its Translation into English").

\section{NOTES}

1. PeOple's DAILY OnLINE (2008): 深入持久地进行改革开放宣传教育 继续把改革开放伟大事业推 向前进 [An in-depth and lasting publicity campaign for the continuous progressing of the great undertaking of reforming and opening-up]. People's Daily Online. 28 December 2008. Visited 9 June 2011, <http://opinion.people.com.cn/GB/8596751.html>.

2. China Daily Online (2008): We'll forge ahead with reforms: Hu. China Daily Online. 19 December 2008. Visited 11 February 2009, <http://www.chinadaily.com.cn/2008-12/19/content_7320302. htm>.

3. Xinhua Online (2009): "Bu zheteng" - almost impossible to translate. Chinaview. Xinhua News Agency. 20 January 2009. Visited 11 February 2009, <http://news.xinhuanet.com/english/200901/20/content_10689692.htm>.

4. People's Daily Online (2009): Hu Jintao's “bu zheteng” baffles foreign media. People's Daily Online. 8 January 2009. Visited 8 June 2011, <http://english.peopledaily.com.cn/90001/90782/90873/ 6570469.html>.

5. People's Daily Online (2009): Chinese ambassador suggests a translation for "bu zheteng." People's Daily Online. 19 January 2009. Visited 8 June 2011, <http://english.peopledaily.com. cn/90001/90782/90873/6576787.html>.

6. Chinese Translators Journal (2009): “不折腾” 英译大家谈 [Experts on the English translation of "bu zheteng"]. Chinese Translators Journal. 30(2):58-61.

7. National Population and Family Planning Commission of the People's Republic of CHINA (2008): 国新办主任王晨解读胡锦涛报告 “不折腾” 内涵 [Wang Chen, director of the Information Office of the State Council, interprets what "buzheteng" means]. Visited 6 June 2011, $<$ http://www.chinapop.gov.cn/wxzl/ztk/kxfzgzt/200812/t20081231_163732.html>.

8. - (2007): Hanyu Da Cidian [Modern Chinese dictionary]. CD-ROM. Hong Kong: The Commercial Press.

9. Wu, JingRong, ed. (1986): Hanying cidian [A Chinese-English dictionary]. Beijing: The Commercial Press.

10. Wu, GuangHua, ed. (1993): Hanying dacidian(xiajuan) [A Chinese-English dictionary (vol. 2)]. Shanghai: Shanghai Jiaotong University Press. 
11. DeFrancis, John, ed. (1997): ABC Chinese-English dictionary. Shanghai: Hanyu Da Cidian Chubanshe.

12. PeOple's Daily OnLine (1998): 在全国政协九届一次会议闭幕会上的讲话 [A speech at the closing session of the 1st plenary meeting of the $9^{\text {th }}$ Chinese People's Political Consultative Conference]. People's Daily Online. 15 March 1998. Visited 21 February 2009, <http://www.people.com.cn/item/ lianghui/ziliao/ljlh/zx/9jie/newfiles/a1240.html>.

13. Xinhua Online (2001): 李瑞环会见巴布亚新几内亚总理 [Li Ruihuan meets with the prime minister of Papua New Guinea]. Xinhua Online. 16 November 2001. Visited 11 June 2011, <http:// news.xinhuanet.com/world/2001-11/16/content_119064.htm>.

14. Unless indicated otherwise, the English translations of the Chinese examples or quotations are the authors. For convenience of discussion, the Chinese phrase (不)折腾 remains (bu) zheteng in these translations.

15. $21^{\text {st }}$ Century Online (2009): No 'zheteng' in 2009! $21^{\text {st }}$ Century Online. 14 January 2009. Visited 16 January 2009, <http://www.21stcentury.com.cn/mod.shtml?n=21st\&ff=ch\&l=echo\&id=3052>.

16. Xinhua OnLine (2009): 調查: 官員不折騰成網友新年最大心願 [Survey: the biggest New Year's wish is no zheteng on the part of government officials]. Xinhua Online. 12 January 2009. Visited 20 November 2010, <http://big5.xinhuanet.com/gate/big5/news.xinhuanet.com/forum/200901/12/content_10617137.htm>.

17. Zeleny, Jeff (2009): Daschle Ends Bid for Post; Obama Concedes Mistake. New York Times. 3 February 2009. Visited 11 June 2011, <http://www.nytimes.com/2009/02/04/us/politics/04obama. html>.

18. Moy, Pasty and Lee, Diana (2009): Chief delays political reform review amid grim jobs warning: hold it. The Standard. 16 January 2009.

19. That the there-be construct is grammatically metaphoric can be seen by comparing 'There is a man at the door' with the less natural or idiomatic 'A man is/stands at the door' (examples and remarks on their "naturalness" adapted from Alexander 1988:194). The latter is more congruent in that it has a more conspicuous presentation of the human agent and is closer to (the perception of) the state of affairs in the real world.

\section{REFERENCES}

Alexander, Louis George (1988): Longman English Grammar. London/New York: Longman.

Bransford, John and MCCARRELl, Nancy (1977): A cognitive approach to comprehension. In: Philip Johnson-Laird and Peter Cathcart Wason, eds. Thinking: Readings in Cognitive Science. Cambridge: Cambridge University Press, 377-399.

Cheng, QiLong (1994): Xitong gongneng yufa daolun [An introduction to systemic-functional grammar]. Shantou: Shantou University Press.

Halliday, Michael Alexander Kirkwood (1985): An Introduction to Functional Grammar. London/New York: Edward Arnold.

Halliday, Michael Alexander Kirkwood (1999): The grammatical construction of scientific knowledge: the framing of the English clause. In: Rema Rossini Favretti, Giorgio SANDri and Roberto SCAZzIERI, eds. Incommensurability and Translation: Kuhnian Perspectives on Scientific Communication and Theory change. Cheltenham/Northampton: Edward Elgar, 85-116.

Halliday, Michael Alexander Kirkwood and Matthiessen, Christian Matthias Ingemar Martin (1998): Construing Experience Through Meaning: A Language-based Approach to Cognition. London/New York: Cassell.

Hernandez-Campoy, Juan Manuel and Cutillas-Espinosa, Juan Antonio (2010): Speaker design practices in political discourse: a case study. Language \& Communication. 30:297309.

Larcker, David Francis and Zakolyukina, Anastasia (2010): Detecting deceptive discussions in conference calls. Stanford GSB Research Paper No. 2060, Rock Center for Corporate Governance Working Paper No. 83. Visited 10 June 2011, <http://gsbapps.stanford.edu/ researchpapers/library/RP2060\%20\&\%2083.pdf>.

LI, RuiHuan (2007): Bianzhengfa suitan [On dialectics]. Beijing: China Renmin University Press. 
Martin, James Robert (2003): Preface. In: Anne-Marie Simon-Vandenbergen, Miriam TAVERniers and Louise RaVelli, eds. Grammatical Metaphor: Views from Systemic Functional Linguistics. Amsterdam/Philadelphia: John Benjamins, 1-3.

Newmark, Peter (2001a): Approaches to Translation. Shanghai: Shanghai Foreign Language Education Press.

Newmark, Peter (2001b): A Textbook of Translation. Shanghai: Shanghai Foreign Language Education Press.

Newton, Natika (1996): Foundations of Understanding. Amsterdam/Philadelphia: John Benjamins Publishing Company.

TAVERniers, Miriam (2003): Grammatical metaphor in SFL: A historiography of the introduction and initial study of the concept. In: Anne-Marie Simon-Vandenbergen, Miriam Taverniers and Louise Ravelli, eds. Grammatical Metaphor: Views from Systemic Functional Linguistics. Amsterdam/Philadelphia: John Benjamins Publishing Company, 5-33.

Thompson, Geoff (1996): Introducing Functional Grammar. London/New York: Arnold.

Venuti, Lawrence (1995): The Translator's Invisibility. London: Routledge.

Venuti, Lawrence (2008): Translation, simulacra, resistance. Translation Studies. 1(1):18-33.

WANG, SongMao, Wu, ZhiXiao, YANG, CongJie et al. (1983): Hanyu daici lijie [Chinese pronouns explained and illustrated]. Beijing: Shumu Wenxian Chubanshe.

YANG, YanNing (2008): Typological interpretation of differences between Chinese and English in grammatical metaphor. Language Sciences. 30(4):450-478.

ZHU, ChunShen (1996): Syntactic status of the agent and information presentation in translating the passive between Chinese and English. Multilingua: Journal of Cross-cultural and Interlanguage Communication. 15(4):397-417.

ZHU, ChunShen and ZHANG, JunFeng (2011): “不折腾” 的不翻译：零翻译、陌生化与话语解 释权 [“bu zheteng” untranslated: zero translation, defamiliarization and the right of discourse interpretation]. Chinese Translators Journal. 32(1):68-72. 